\title{
Prostanoid synthesis by cultured intestinal epithelial and mononuclear cells in inflammatory bowel disease
}

\author{
A ZIFRONI, A J TREVES, D B SACHAR, AND D RACHMILEWITZ
}

From the Departments of Gastroenterology, Radiation, and Clinical Oncology, Hadassah University Hospital, Jerusalem, Israel, and Department of Gastroenterology, Mount Sinai School of Medicine, New York, USA

SUMmARY Intestinal epithelial and mononuclear cells were isolated from normal colonic mucosa and from intestinal mucosa of inflammatory bowel disease patients. Prostanoid synthesis by primary cultures of intestinal mononuclear cells were four to six fold higher than its synthesis by primary cultures of epithelial cells. Prostaglandin $\mathrm{E}_{2}$, prostacyclin and thromboxane $\mathrm{A}_{2}$ synthesis by cultured mononuclear cells isolated from inflamed ileal mucosa of four Crohn's disease patients: $5 \cdot 6 \pm 1 \cdot 2 ; 3 \cdot 2 \pm 1.9$ and $2 \cdot 4 \pm 1 \cdot 4$ (mean $\pm S E$ ) $\mathrm{ng} / 1 \times 10^{6}$ cells were significantly higher than their respective synthesis by cultured mononuclear cells isolated from uninflamed ileal mucosa isolated from the same patients: $0 \cdot 8 \pm 0 \cdot 1 ; 0 \cdot 3 \pm 0 \cdot 1$ and $0 \cdot 2 \pm 0 \cdot 03 \mathrm{ng} / 1 \times 10^{6}$ cells or from normal colonic mucosa: $1 \cdot 5 \pm 0 \cdot 3 ; 0 \cdot 3 \pm 0 \cdot 1$ and $0.5 \pm 0 \cdot 1(\mathrm{~N}=12) \mathrm{ng} / 1 \times 10^{6}$ cells. Prostanoid synthesis by primary cultures of intestinal mononuclear cells isolated from colonic mucosa of five ulcerative colitis patients was enhanced but not significantly different from its synthesis by cells isolated from normal subjects. These results suggest that the enhanced intestinal prostanoid synthesis in active Crohn's disease is derived from stimulated local mononuclear cells and may. have an important role in the pathogenesis of the disease.

Inflammatory cells, as well as several mediators, are suggested to have a role in the pathogenesis of ulcerative colitis and Crohn's disease. We have reported enhanced colonic synthesis of prostaglandin $\mathrm{E}_{2}\left(\mathrm{PGE}_{2}\right)$, thromboxane $\mathrm{A}_{2}\left(\mathrm{TXA}_{2}\right)$ and prostacyclin $\left(\mathrm{PGI}_{2}\right)$ in active ulcerative colitis ${ }^{12}$ and lately also in Crohn's disease. ${ }^{3}$ Prostaglandins and thromboxanes (prostanoids) may be important not only as mediators of inflammation ${ }^{4}$ but also in the alteration of secretory and absorptive functions ${ }^{5}$ and in the impairment of cell mediated immunity. ${ }^{6}$

Both colonic epithelial and mononuclear cells synthesise prostanoids. The enhanced colonic prostanoid synthesis can thus be because of either an increase in the number of intestinal mononuclear cells and/or an enhanced endogenous synthesis by one or both types of cells.

Intestinal mononuclear cells originate in the bone marrow and circulate in the blood. ${ }^{7}$ Peripheral

\footnotetext{
Address for correspondence: Daniel Rachmilewitz, MD, Department of Gastroenterology, Hadassah University Hospital, P.O.B. 12000, Jerusalem, Israel.

Received for publication 4 October 1982
}

blood mononuclear cells may also have an important role in the pathogenesis of inflammatory bowel disease: patients with inflammatory bowel disease have circulating $\mathrm{T}$ lymphocytes which have been sensitised to a multiplicity of colon and bacterial antigens. ${ }^{8}$ We have reported enhanced $\mathrm{PGE}_{2}$ and $\mathrm{TXA}_{2}$ synthesis by cultured peripheral blood mononuclear cells in Crohn's disease. ${ }^{9}$

The aim of the present study was to utilise the mechanical and enzymatic methods to isolate intestinal epithelial and mononuclear cells in order to characterise the type of cell responsible for the enhanced intestinal prostanoid synthesis in inflammatory bowel disease and thus to better understand their possible role in the pathogenesis of the disease.

\section{Methods}

SUBJECTS

Colonic mucosa was obtained at surgery from five patients with ulcerative colitis who underwent total colectomy. Four of them were under steroid therapy at time of sugery. Inflamed ileal mucosa and normal ileal mucosa adjacent to areas of active disease were 
obtained from four patients with Crohn's disease who underwent surgery, none of whom received steroids at least one month before the operation. None of the patients had ever received azathioprine or 6-mercaptopurine. For comparison, colonic tissue was obtained at surgery from 12 patients with adenocarcinoma of the colon from sites at least $10 \mathrm{~cm}$ from areas of disease and were both grossly and histologically normal.

\section{ISOLATION OF INTESTINAL EPITHELIAL AND} MONONUCLEAR CELLS

Intestinal epithelial and mononuclear cells were isolated according to Bull and Bookman ${ }^{10}$ with some modidfications: Four $10 \mathrm{~g}$ pieces of intestinal mucosa were dissected from the underlying muscularis using iris scissors, cut into small fragments, washed in calcium and magnesium-free phosphate buffered saline (PBS, GIBCO, Grand Island, NY) and incubated with stirring for 10 minutes at room temperature in phosphate buffered saline containing $1 \mathrm{mM}$ dithiothreitol (DDT) (Sigma Chemical Co, St Louis, Ma.) for removal of adherent mucus. Epithelial cells were removed by stirring the tissue with phosphate buffered saline containing $0.75 \mathrm{mM}$ EDTA, pH 7.2, for 90 minutes at $37^{\circ} \mathrm{C}$. This procedure was repeated twice and following centrifugation (1000 rpm for 5 minutes) the epithelial cells were found in the supernatant. The epithelial cells were identified by morphological criteria of perparations stained with Giemsa.

The mucosal pieces were then washed in phosphate buffered saline and incubated overnight with gentle shaking at $37^{\circ} \mathrm{C}$ in RPMI-1640 (GIBCO) containing $5 \%$ heat-inactivated pooled human $\mathrm{AB}$ serum (HS); antibiotics (penicillin $100 \mathrm{U} / \mathrm{ml}$, streptomycin $100 \mu \mathrm{g} / \mathrm{ml}$, Fungizone $50 \mathrm{U} / \mathrm{ml}$, gentamicin 50 $\mu \mathrm{g} / \mathrm{ml})$; collagenase $(0.05 \mathrm{mg} / \mathrm{ml} ;$ CLS, Worthington Biochem Corp, Freehold, NJ); MEM vitamin solution (1:100); L-glutamine $2 \mathrm{mM}$ and sodium pyruvate $1 \mathrm{mM}$. The resultant cell suspension in each stage of the isolation procedure was washed and resuspended. $2 \times 10^{6}$ cells in $1 \mathrm{ml}$ of supplemented RPMI-1640 containing $2 \%$ HS were incubated for 18 hours in $5 \% \mathrm{CO}_{2}$ in air in a humidified incubator. Mononuclear cells were also identified by Giemsa stain.

\section{VIABILITY TESTING AND COUNTING}

Cell viability was assessed by exclusion of $0.04 \%$ trypan-blue. Mononuclear and epithelial cells were counted in a haemocytometer and differentiated according to their size and morphology.

MONONUCLEAR CELL CHARACTERISATION Monocytes and macrophages were depleted by incubation of $2 \times 10^{6}$ cells in $1 \mathrm{ml}$ of supplemented medium containing $2 \%$ human serum in multiwell plates (Linbro, Hamden, CT) for 90 minutes. The non-adherent cells (more than $95 \%$ of which are lymphocytes) were then removed by repeated pipetting and reincubated. Fresh medium was added to the remaining adherent cells. Further depletion of phagocytic cells was achieved by incubating 5$20 \times 10^{6}$ cells for 60 minutes in $5 \mathrm{ml}$ of medium containing $50 \mathrm{mg}$ of carbonyl iron (Gaf Inc, New York, NY) in a test tube. Phagocytic cells and remaining carbonyl iron were attracted by a magnet to the bottom of the tube and the cells remaining in the supernatant were collected as previously described. ${ }^{11}$

Phagocytic activity was determined by incubating $2 \times 10^{6}$ cells for 16 hours in $1 \mathrm{ml}$ of culture medium in silicone coated glass test tube containing $0.2 \%$ suspension of latex particles $(0.8 \mu$ diameter, Sigma). Cells containing more than five latex particles were scored as phagocytic cells.

\section{SECRETION OF PROSTAGLANDINS}

Cell cultures were incubated for 18 hours, in the presence or absence of $1-10 \mu \mathrm{g} / \mathrm{ml}$ of lipopolysaccharide W (LPS. S. Typhimurium, Difco Laboratories, Detroit, MI). Control cultures contained the culture medium without cells. At the end of the incubation the medium was collected, centrifuged for 5 minutes at $800 \mathrm{~g}$ and frozen immediately at $-20^{\circ} \mathrm{C}$.

$\mathrm{PGE}_{2}$, 6-keto-PGF $1 \alpha$, the stable metabolite of $\mathrm{PGI}_{2}$, and $\mathrm{TXB}_{2}$, the stable metabolite of $\mathrm{TXA}_{2}$, were determined by a radioimmunoassay as previously described, ${ }^{9} 12$ and calculated per $1 \times 10^{6}$ cells.

Statistical analysis was performed according to the Student's $t$ test for unpaired data.

\section{Results}

The first stage of the isolation procedure, treating intestinal mucosa with dithiothreitol, yielded mainly red blood cells and some leukocytes most of them polymorphonuclears. The two subsequent stages of isolation with EDTA resulted in suspensions consisting of $71-83 \%$ of epithelial cells which were $90 \%$ viable by trypan-blue exclusion. No significant changes in cell viability were observed after 18 hours of culture. The cells isolated in this stage were defined as the epithelial cell fraction (Table 1). The mononuclear cell fraction obtained by dissociation of the lamina propria with collagenase and human serum, consisted of mononuclear enriched cell suspensions ( $72-94 \%$ of the total cells). One gram of dissected intestinal mucosa yielded 5-25 million 
Table 1 Distribution of epithelial and mononuclear cells among subfractions of intestinal mucosa

\begin{tabular}{|c|c|c|c|c|c|}
\hline & & \multicolumn{2}{|c|}{ Epithelial fraction } & \multicolumn{2}{|c|}{ Mononuclear fraction } \\
\hline & & Epithelial & $\begin{array}{l}\text { Mono- } \\
\text { nuclear }\end{array}$ & Epithelial & $\begin{array}{l}\text { Mono- } \\
\text { nuclear }\end{array}$ \\
\hline \multicolumn{6}{|c|}{ No.\% of total (mean $\pm S E$ ) } \\
\hline $\begin{array}{l}\text { Normal mucosa } \\
\text { Crohn's disease } \\
\text { Ulcerative colitis }\end{array}$ & $\begin{array}{r}12 \\
4 \\
5\end{array}$ & $\begin{array}{l}83 \pm 3 \\
71 \pm 9 \\
78 \pm 6\end{array}$ & $\begin{array}{l}17 \pm 3 \\
29 \pm 9 \\
22 \pm 6\end{array}$ & $\begin{array}{r}6 \pm 1 \\
18 \pm 2 \\
28 \pm 2\end{array}$ & $\begin{array}{l}94 \pm 1 \\
81 \pm 7 \\
72 \pm 4\end{array}$ \\
\hline
\end{tabular}

Colonic epithelial and mononuclear cells were isolated, identified and counted as described in Methods.

mononuclear cells, which were over $95 \%$ viable by trypan-blue exclusion before and after 18 hours of culture.

During 18 hours of culture both epithelial and mononuclear cells isolated from all groups of patients were found to secrete $\mathrm{PGE}_{2}, \mathrm{PGI}_{2}$ and $\mathrm{TXA}_{2}$ to the culture medium.

Cultured epithelial cells isolated from normal colonic mucosa obtained from patients with adenocarcinoma of the colon secreted to the medium similar amounts of all three prostanoids tested (Table 2).

$\mathrm{TXA}_{2}$ accumulation by cultured epithelial cells isolated from intestinal mucosa of both Crohn's disease and ulcerative colitis patients was significantly higher than its accumulation by cells obtained from normal mucosa. Accumulation of $\mathrm{PGE}_{2}$ was significantly increased only by epithelial enriched cell suspensions isolated from Crohn's disease patients. There was no significant difference in $\mathrm{PGI}_{2}$ secretion among the three groups of patients.
Accumulation of the three prostanoids tested by cultured epithelial cell suspensions depleted of adherent and phagocytic cells was not significantly different from their respective accumulation by the crude cell suspensions (Table 2). Mononuclear cells isolated from normal mucosa secreted four times more $\mathrm{PGE}_{2}$ and twice more $\mathrm{PGI}_{2}$ and $\mathrm{TXA}_{2}$ than isolated epithelial cells (Tables 2 and 3 ). Synthesis of the three prostanoids by cultured mononuclear cells was significantly higher than their respective synthesis by cultured epithelial cells in all groups of patients (Tables 2 and 3 ).

$\mathrm{PGE}_{2}, \mathrm{TXA}_{2}$ and $\mathbf{P G I}_{2}$ secretion by cultured mononuclear cells isolated from normal appearing mucosa adjacent to areas of active disease in the Crohn's disease patients was similar to their secretion by cells isolated from normal mucosa in cancer patients: $0.78 \pm 0.10 ; 0.33 \pm 0.06$ and $0 \cdot 19 \pm 0.03 \mathrm{ng} / 1 \times 10^{6}$ cells respectively.

$\mathrm{PGE}_{2}$ secretion by mononuclear cells isolated from inflamed mucosa of Crohn's disease patients was four times higher than its secretion by cells isolated from normal mucosa obtained from cancer patients $(\mathrm{p}<0 \cdot 01)$. $\mathrm{PGI}_{2}$ and $\mathrm{TXA}_{2}$ secretion were five to nine times higher $(p<0.05)$ (Table 3$)$.

Secretion of the three prostanoids by cultured mononuclear cells isolated from ulcerative colitis patients receiving steroid treatment was higher but not significantly different from their secretion by cells isolated from normal mucosa of adenocarcinoma patients.

Mononuclear cells obtained from the only ulcerative colitis patient with no steroid treatment secreted the highest amounts of $\mathrm{PGE}_{2}, \mathrm{PGI}_{2}$ and TXA $_{2}$ in this group of patients: $11 \cdot 0,4 \cdot 2$, and 23.0 $\mathrm{ng} / 1 \times 10^{6}$ cells respectively. Depletion of adherent and phagocytic cells from the mononuclear enriched

Table 2 Prostanoid accumulation by cultured intestinal epithelial cells

\begin{tabular}{|c|c|c|c|c|}
\hline & & Normal mucosa & Crohn's disease & Ulcerative colitis \\
\hline & & \multicolumn{3}{|c|}{$\left(\mathrm{ng} / 1 \cdot 10^{6}\right.$ cells/18 h mean $\left.\pm S E\right)$} \\
\hline $\mathrm{PGE}_{2}$ & $\begin{array}{l}\text { All cells } \\
\text { Non-adherent } \\
\text { Non-phagocytic }\end{array}$ & $\begin{array}{l}0.38 \pm 0.08 \\
0.27 \pm 0.02\end{array}$ & $\begin{array}{l}0.99 \pm 0.34 \dagger \\
1.38 \pm 0.64 \dagger\end{array}$ & $\begin{array}{l}0.78 \pm 0.32 \\
0 \cdot 67 \pm 0 \cdot 19^{*}\end{array}$ \\
\hline 6-keto-PGF $1 \alpha$ & $\begin{array}{l}\text { All cells } \\
\text { Non-adherent } \\
\text { Non-phagocytic }\end{array}$ & $\begin{array}{l}0 \cdot 18 \pm 0.09 \\
0 \cdot 24 \pm 0 \cdot 15\end{array}$ & $\begin{array}{l}0.27 \pm 0.08 \\
0.08 \pm 0.01\end{array}$ & $\begin{array}{l}0.28 \pm 0.13 \\
0.16 \pm 0.03\end{array}$ \\
\hline $\mathbf{T X B}_{\mathbf{2}}$ & $\begin{array}{l}\text { All cells } \\
\text { Non-adherent } \\
\text { Non-phagocytic }\end{array}$ & $\begin{array}{l}0 \cdot 20 \pm 0.04 \\
0 \cdot 18 \pm 0.03\end{array}$ & $\begin{array}{l}0.82 \pm 0.30^{*} \\
0.93 \pm 0.49 \dagger\end{array}$ & $\begin{array}{l}5 \cdot 46 \pm 3 \cdot 50 \dagger \\
3 \cdot 58 \pm 1 \cdot 54^{*}\end{array}$ \\
\hline
\end{tabular}

Epithelial cells were isolated from intestinal mucosa, adherent, and phagocytic cells were depleted and cultured for $18 \mathrm{~h}$ as described in Methods. Prostanoids accumulation in medium was determined by radioimmunoassay. Significantly different from prostanoid synthesis by cells isolated from normal mucosa.

* $\mathrm{p}<0.01$. $\uparrow \mathrm{p}<0.05$. 
Table 3 Prostanoid accumulation by cultured intestinal mononuclear cells

\begin{tabular}{|c|c|c|c|c|}
\hline & & Normal mucosa & Crohn's disease & Ulcerative colitis \\
\hline & & \multicolumn{3}{|c|}{$\left(\mathrm{ng} / 1 \cdot 10^{6} \mathrm{cells} / 18 \mathrm{~h}\right.$ mean $\left.\pm S E\right)$} \\
\hline $\mathrm{PGE}_{2}$ & $\begin{array}{l}\text { All cells } \\
\text { Non-adherent } \\
\text { Non-phagocytic }\end{array}$ & $\begin{array}{l}1 \cdot 5 \pm 0.3 \\
1 \cdot 3 \pm 0.3\end{array}$ & $\begin{array}{l}5 \cdot 6 \pm 1 \cdot 2^{*} \\
4 \cdot 9 \pm 2 \cdot 1\end{array}$ & $\begin{array}{l}4 \cdot 0 \pm 2 \cdot 0 \\
6 \cdot 1 \pm 4 \cdot 2\end{array}$ \\
\hline 6-keto-PGF $1 \alpha$ & $\begin{array}{l}\text { All cells } \\
\text { Non-adherent } \\
\text { Non-phagocytic }\end{array}$ & $\begin{array}{l}0.3 \pm 0.1 \\
0.2 \pm 0.1\end{array}$ & $\begin{array}{l}3 \cdot 2 \pm 1 \cdot 9 \dagger \\
1 \cdot 6 \pm 0 \cdot 3^{*}\end{array}$ & $\begin{array}{l}1 \cdot 4 \pm 0 \cdot 7 \\
2 \cdot 2 \pm 1 \cdot 7\end{array}$ \\
\hline $\mathbf{T X B}_{2}$ & $\begin{array}{l}\text { All cells } \\
\text { Non-adherent } \\
\text { Non-phagocytic }\end{array}$ & $\begin{array}{l}0 \cdot 5 \pm 0 \cdot 1 \\
0 \cdot 3 \pm 0 \cdot 1\end{array}$ & $\begin{array}{l}2.4 \pm 1.4 \dagger \\
2.4 \pm 1.7\end{array}$ & $\begin{array}{l}5 \cdot 9 \pm 4 \cdot 3 \\
9 \cdot 6 \pm 8 \cdot 1\end{array}$ \\
\hline
\end{tabular}

Mononuclear cells were isolated from intestinal mucosa, adherent, and phagocytic cells were depleted and cultured for $18 \mathrm{~h}$ as described in Methods. Prostanoids accumulation in medium was determined by radioimmunoassay. Significantly different from prostanoid synthesis by cells isolated from normal mucosa.

$* \mathrm{p}<0 \cdot 01 .+\mathrm{p}<0.05$.

cell suspension isolated from the three groups of patients did not alter the accumulation of the three prostanoids (Table 3). Addition of lipopolysaccharide to the cultured mononuclear cells also did not affect secretion of the three prostanoids (results not shown).

\section{Discussion}

Prostanoid ( $\mathrm{PGE}_{2}, \mathrm{PGI}_{2}$ and $\mathrm{TXA}_{2}$ ) synthesis by the inflamed colonic mucosa has previously been shown to be enhanced in active ulcerative colitis and Crohn's disease..$^{1-3}$ It was also suggested that the mechanisms responsible for the therapeutic effects of steroids and sulphasalazine in inflammatory bowel disease may be related to their inhibition of colonic prostanoid synthesis. ${ }^{2}$ In the present study the combined mechanical and enzymatic methods to isolate intestinal epithelial and mononuclear cells ${ }^{10}$ were utilised in order to characterise the type of cell responsible for the enhanced intestinal prostanoid synthesis in inflammatory bowel disease.

Prostanoid synthesis by primary cultures of epithelial and mononuclear cells isolated from inflamed and uninflamed ileal mucosa of Crohn's disease patients, from colonic mucosa of ulcerative colitis patients was determined and compared with prostanoid synthesis by cells isolated from normal colonic mucosa of cancer patients. The finding that prostanoid synthesis by cultured mononuclear cells isolated from normal, uninflamed ileal mucosa of Crohn's disease patients is similar to that of cultured mononuclear cells isolated from normal colonic mucosa of cancer patients, indicates that prostanoids synthesis by mononuclear cells isolated from normal ileal and colonic mucosa is similar, and validates the use of cells isolated from the colon of cancer patients as a control.

Cultured epithelial enriched cell suspensions isolated from normal colonic mucosa were found to secrete $\mathrm{PGE}_{2}, \mathrm{PGI}_{2}$ and $\mathrm{TXA}_{2}$. $\mathrm{PGE}_{2}$ and $\mathrm{TXA}_{2}$ secretion by cultured epithelial cells isolated from patients with active Crohn's disease were found to be significantly higher than their secretion by cultured epithelial cells isolated from normal mucosa. TXA 2 secretion by cultured epithelial cells isolated from patients with ulcerative colitis was also stimulated, whereas enhanced $\mathrm{PGE}_{2}$ secretion was observed only by the non-adherent non-phagocytic cells.

The synthesis of all three prostanoids tested, by cultured intestinal mononuclear cells, was significantly stimulated only by cells isolated from inflamed sites of patients with Crohn's disease. Intestinal mononuclear cells originate in the bone marrow and circulate in the blood. ${ }^{7}$ We have recently reported enhanced $\mathrm{PGE}_{2}$ and $\mathrm{TXA}_{2}$ synthesis by cultured peripheral blood mononuclear cells also only in patients with active Crohn's disease but not in patients with active ulcerative colitis. ${ }^{9}$ This difference may be because of the presence of a prostanoid inhibitor or a different subset of mononuclear cells in ulcerative colitis as previously suggested, ${ }^{9}$ or more likely owing to the fact that four out of the five ulcerative colitis patients included in the present study were under heavy steroid treatment. Corticosteroids inhibit prostanoid synthesis by limiting the substrate availability. ${ }^{13}$ It is of interest to note that the highest concentration of prostanoid synthesis by cultured intestinal mononuclear cells was observed in the only patient with ulcerative colitis who did not receive steroids for one month before surgery.

Both the epithelial and the mononuclear cell 
fractions were not pure. Each fraction contains variable proportions of the other cell poplation. As, however, the mononuclear cell fraction isolated from patients with active Crohn's disease was found to secrete at least four times more prostanoids than the epithelial cell fraction it is highly suggestive that this cell fraction is responsible for most of the enhanced synthesis observed in this disease. It may very well be that prostanoid synthesis by the epithelial enriched cell suspensions is derived from the presence of mononuclear cells contaminating this fraction.

Plastic adherence and phagocytic activity are among the most useful criteria to identify and isolate monocytes and macrophages. ${ }^{11} \mathrm{We}^{11}$ and others ${ }^{14}$ have previously reported that most of prostanoid secretion by cultured peripheral blood mononuclears is derived from the adherent phagocytic cell population. In the present study, however, in which prostanoid synthesis by cultured mononuclear cells isolated from intestinal mucosa was determined, depletion of adherent and phagocytic cells did not affect their synthesis. The different origin of the mononuclear cells in both studies - that is, peripheral blood and intestinal mucosa - may explain this observation. The mechanism responsible for this difference is not clear and has to be elaborated.

In the cell suspensions obtained from the chronically inflamed mucosa of inflammatory bowel disease patients and from normal subjects, polymorphonuclear cells were not identified. This is in agreement with the established observation that mononuclear cells predominate in chronic inflammatory conditions.

The addition of lipopolysaccharide to the medium also did not stimulate prostanoid synthesis by intestinal mononucler cells. This observation further supports the contention that mononuclear cells responsible for most of the intestinal prostanoid production are different from adherent phagocytic cells.

In conclusion, the cumulative data suggest that mononuclear cells have an important role in prostanoid synthesis by normal colonic mucosa as well as by the inflamed intestinal mucosa in inflammatory bowel disease patients. Moreover, the cells responsible for most of the prostanoid production are probably not part of the monocyte macrophage system and may represent lymphoid cells. Lamina propria lymphoid cells have been recently under extensive investigation. ${ }^{10}{ }^{15-18}$ Their location within the mucosa as well as their increase in number in active inflammatory bowel disease ${ }^{19}$ suggests their role in immunological reactions which may lead to intestinal damage. Prostanoids mediate inflam- matory response ${ }^{4}$ immune precursor cell proliferation $^{20}$ and regulate several mature immune cell functions. ${ }^{21}$ The enhanced intestinal prostanoid production derived from stimulated local mononuclear cells may thus have an important role in the pathogenesis of inflammatory bowel disease.

This study was supported in part by a grant from the National Foundation for Ileitis and Colitis, Inc, and by a grant from the Ministry of Health of the State of Israel to DR. This work was presented in part at the annual meeting of the American Gastroenterological Association, Chicago, May 1982 and was published as an abstract in Gastroenterology, May 1982.

\section{References}

1 Sharon P, Ligumsky M, Rachmilewitz D et al. Role of prostaglandins in ulcerative colitis. Enhanced production during active disease and inhibition by sulfasalazine. Gastroenterology 1978; 75: 638-40.

2 Ligumsky M, Karmeli F, Sharon $\mathrm{P}$ et al. Enhanced thromboxane $\mathrm{A}_{2}$ and prostacyclin production by cultured rectal mucosa in ulcerative colitis and its inhibition by steroids and sulfasalazine. Gastroenterology 1981; 81: 444-9.

3 Rachmilewitz D, Karmeli F, Zifroni A et al. Enhanced intestinal prostanoid synthesis in Crohn's disease. (Abstract). Gastroenterology 1982; 82: 1154.

4 Higgs GA, Moncada S, Vane JR. The role of arachidonic acid metabolites in inflammation. In: Weissman $\mathrm{G}$ et al, eds. Advances in inflammation research, vol 1. New York: Raven Press, 1979: 413-8.

5 Strickland RG, Sachar DB. The immunologv of inflammatory bowel disease. Progress in gastroenterology 1977; 3: 821-38.

6 Goodwin JS, Messner RP, Bankhurst AD et al. Prostaglandin-producing suppressor cells in Hodgkin's disease. N Engl J Med 1977; 297: 963-8.

7 Spector WG. The macrophage in inflammation. Ser Haematol 1970; 3: 132-44.

8 Meuwissen SGU, Nadorp JHSM, Tytgat GNJ. Crohn's disease: a review of immunopathological aspects. Neth J Med 1977; 20: 78-9.

9 Rachmilewitz D, Ligumsky M, Haimovitz A et al. Prostanoid synthesis by cultured peripheral blood mononuclear cells in inflammatory diseases of the bowel. Gastroenterology 1982; 82: 673-9.

10 Bull PM, Bookman MA. Isolation and functional characterization of human intestinal mucosal lymphoid cells. J Clin Invest 1977; 59: 966-74.

11 Treves JA, Yagoda D, Haimovitz A et al. The isolation and purification of human peripheral blood monocytes in cell suspension. J Immunol Methods 1980; 39: 71-80. 12 Bauminger S, Zor U, Lindner HR. Radioimmuno- 
logical assay of prostaglandin synthetase activity. Prostaglandins 1973; 4: 313-24.

13 Flower RJ, Blackwell CJ. Anti-inflammatory steroids induced biosynthesis of a phospholipase $\mathrm{A}_{2}$ inhibitor which prevents prostaglandin generation. Nature 1979; 278: 456.

14 Kennedy MS, Stobo JD, Goldyne ME. In vitro synthesis of prostaglandins and related lipids by populations of human peripheral blood mononuclear cells. Prostaglandins 1980; 20: 135-45.

15 Bookman MA, Bull DM. Characteristics of isolated intestinal mucosal lymphoid cells in inflammatory bowel. Gastroenterology 1982: 82: 673-9.

16 Fiocci C, Battisto JR, Farmer KG. Gut mucosal lymphocytes in inflammatory bowel disease. Dig Dis Sci 1979; 24: 705-16.

17 Bartnik W, ReMine SG, Chiba M et al. Isolation and characterization of colonic intraepithelial and lamina propria lymphocytes. Gastroenterology 1980; 78: 97685.

18 Falchuk ZM, Barnhard E, Machado I. Human colonic mononuclear cells: studies of cytotoxic function. Gut 1981; 22: 290-94.

19 Morson BC. Pathology of ulcerative colitis. In: Kirsner JB, Shorter RH, eds. Inflammatory bowel disease. Philadelphia: Lea and Febiger, 1975: 167-81.

20 Bockman RS, Rothschild M. Prostaglandin E inhibition of T-lymphocyte colony formation: possible mechanism of monocyte modulation of clonal expansion. J Clin Invest 1979; 64: 812-9.

21 Droller MJ, Schneider MU, Perlman P. A possible role of prostaglandins in the inhibition of natural and antibody dependent cell-mediated cytotoxicity against tumor cells. Cell Immunol 1978; 39: 165-77. 